\title{
Evaluation of candidate reference genes for quantitative real-time PCR analysis in a male rat model of dietary iron deficiency
}

\author{
Joanna L. Fiddler ${ }^{1,2^{*}}$ (1) and Stephen L. Clarke ${ }^{2}$
}

\begin{abstract}
Background: Quantitative real-time polymerase chain reaction ( $q P C R$ ) is a reliable and efficient method for quantitation of gene expression. Due to the increased use of $\mathrm{QPCR}$ in examining nutrient-gene interactions, it is important to examine, develop, and utilize standardized approaches for data analyses and interpretation. A common method used to normalize expression data involves the use of reference genes (RG) to determine relative mRNA abundance. When calculating the relative abundance, the selection of RG can influence experimental results and has the potential to skew data interpretation. Although common RG may be used for normalization, often little consideration is given to the suitability of RG selection for an experimental condition or between various tissue or cell types. In the current study, we examined the stability of gene expression using BestKeeper, comparative delta quantitation cycle, NormFinder, and RefFinder in a variety of tissues obtained from iron-deficient and pair-fed ironreplete rats to determine the optimal selection among ten candidate RG.

Results: Our results suggest that several commonly used RG (e.g., Actb and Gapdh) exhibit less stability compared to other candidate RG (e.g., Rp/19 and Rps29) in both iron-deficient and iron-replete pair-fed conditions. For all evaluated RG, Tfrc expression significantly increased in iron-deficient animal livers compared to the iron-replete pairfed controls; however, the relative induction varied nearly 4-fold between the most suitable (Rp/19) and least suitable (Gapdh) RG.
\end{abstract}

Conclusion: These results indicate the selection and use of RG should be empirically determined and RG selection may vary across experimental conditions and biological tissues.

Keywords: Anemia, housekeeping genes, normalization genes, mRNA expression, quantitative real-time PCR

\section{Background}

Iron is an essential nutrient and is involved in many mammalian processes including DNA synthesis, erythropoiesis, ATP production, and oxygen transport $[1,2]$. In humans, iron deficiency (ID) remains the most common single nutrient deficiency and affects approximately $25 \%$ of the world's population or 1.62 billion people according to the World Health Organization [3]. Due to its

\footnotetext{
* Correspondence: jff299@cornell.edu

'Division of Nutritional Sciences, Cornell University, Ithaca, NY 14850-6301, USA

${ }^{2}$ Department of Nutritional Sciences, Oklahoma State University, Stillwater, OK 74078, USA
}

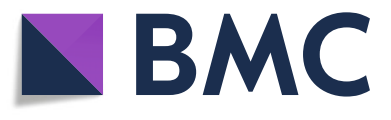

() The Author(s). 2021 Open Access This article is licensed under a Creative Commons Attribution 4.0 International License, which permits use, sharing, adaptation, distribution and reproduction in any medium or format, as long as you give

appropriate credit to the original author(s) and the source, provide a link to the Creative Commons licence, and indicate if changes were made. The images or other third party material in this article are included in the article's Creative Commons licence, unless indicated otherwise in a credit line to the material. If material is not included in the article's Creative Commons licence and your intended use is not permitted by statutory regulation or exceeds the permitted use, you will need to obtain permission directly from the copyright holder. To view a copy of this licence, visit http://creativecommons.org/licenses/by/4.0/.

importance in biological functions, inadequate levels of iron lead to microcytic anemia, diminished cognitive development, and decreased ATP production $[1,4]$.

A variety of biomarkers and methodologies exist to investigate iron status; for example, measuring serum ferritin and transferrin saturation are common practices and often employed together to enhance the detection of systemic ID [5]. To investigate the iron content of biological tissues, inductively coupled plasma mass spectrometry is a useful strategy due to its low detection limits [6]. In many instances, however, indirect measures are needed to further understand iron homeostasis. In these instances, the addition of immunoblotting, 
quantitative real-time PCR (qPCR), and iron regulatory protein (IRP) RNA-binding assays can be utilized to determine the abundance of proteins such as ferritin and transferrin receptor [7], the gene expression of mRNA encoding proteins such as transferrin receptor or hepcidin [8], and IRP-binding activity, respectively [9]. Of these approaches, qPCR has become the gold standard for evaluating gene expression due to its sensitivity, accuracy, and simplicity $[10,11]$. Therefore, fully understanding this technique and standardizing the methods, along with analyzing and interpreting $\mathrm{qPCR}$ results, are of great importance.

To compare differences in gene expression (i.e., mRNA abundance) between experimental groups, qPCR is used by applying Kary Mullis' novel method of amplifying DNA and using probe-based chemistries [11-13]. Following exposure to experimental conditions, there are 4 major steps to successfully complete qPCR: (1) harvest quality RNA from experimental groups, (2) reverse transcribe RNA templates into complementary DNA (cDNA), (3) amplify cDNA with probe-based chemistries by qPCR, and (4) quantify relative mRNA abundance. First, it is essential that RNA integrity is maintained during isolation and purification as poor quality RNA may compromise experimental results [14]. Second, since qPCR amplifies only DNA by taking advantage of DNA polymerases, the quality RNA must be reverse transcribed into cDNA by the enzyme reverse transcriptase [11]. The third step, amplification of the cDNA, utilizes fluorescence-based molecules that bind to DNA and fluoresce following excitation. As each qPCR cycle is repeated, new copies of the cDNA template are generated. Thus, the fluorescence signal is directly proportional to the abundance of DNA. Finally, to quantify relative mRNA abundance, it is important to control for sample-to-sample variation by one of two strategies, the standard curve method or the comparative CT method. Both methods amplify a target gene and a control gene. The standard curve method expresses the relative mRNA abundance to the standard curve of the calibrator (i.e., untreated sample) and the comparative CT method normalizes the threshold cycle values of the target gene to the control gene before comparing experimental groups.

The normalization process accounts for discrepancies in RNA isolation, reverse transcription, and qPCR [15, 16]. Normalization utilizes invariant control genes that are typically referred to as "housekeeping" or "reference" genes (RG) [17]. Ideally, RG have minimal variation in tissue or cell type and under different experimental conditions; thus, RG are considered stable. Interestingly, many RG have been reported to be regulated by experimental conditions or tissue type [18] and subsequently influence gene expression interpretation [15].
To date, there are many studies on RG selection for a number of animal and cell models [19-22]; however, there is limited data regarding RG selection in animal models of dietary conditions. Consequently, the absence of a systematic approach to RG selection makes gene expression data potentially difficult to interpret and compare between studies, and therefore less reliable. For instance, Suzuki et al. [23] reported Gapdh and Actb were used as RG in more than $60 \%$ of articles they reviewed in high-impact journals. While these RG may have been appropriate in those studies, both are affected by hypoxia and cell cycle maturation [24, 25], and tissue type [26]. Furthermore, a commonly used iron-chelating reagent, desferrioxamine, is considered a hypoxiamimetic which may also regulate these RG. Some progress has been made in terms of RG selection in certain models, though the extent to which these results can be applied to all models remains unclear [16, 21]. The focus of this study was to examine RG stability in a weanling rat model of dietary ID and to determine appropriate RG for use in qPCR. Additionally, the extent to which these RG were responsive to dietary ID was assessed. We examined the stability of gene expression in ten commonly used RG in qPCR (Actb, Gapdh, Hprt, Ppia, Rpl19, Rpl22, Rpl27, Rplp0, Rps29, and Tbp) for their candidacy to be used when comparing iron-deficient and iron-replete pair-fed (PF) rat experimental conditions. RG stability was also determined for individual tissues including the gastrocnemius, heart, kidney, liver, lung, and spleen under the same experimental conditions. Using four RG computational programs (BestKeeper, comparative delta quantification cycle $(\Delta \mathrm{Cq})$, NormFinder, and RefFinder), we analyzed the gene stability to predict the most suitable RG for studying the effects of dietary ID on the regulation of gene expression $[2,20$, 22, 27].

\section{Results}

Animal anthropometric data and iron status measurements throughout the study are published elsewhere [28]. In summary, the ID group exhibited greater than $50 \%$ reduction in hemoglobin, hematocrit, and serum iron levels compared to both the control $(\mathrm{C})$ and $\mathrm{PF}$ groups. ID animals weighed $\sim 20 \%$ less than the $\mathrm{C}$ group; therefore, to control for the total diet consumed, the PF group was fed an iron-sufficient diet to the level of the ID group's daily consumption. Importantly, there were no differences in final body weight or rate of weight gain between PF and ID groups. These results are consistent with previous findings indicating that ID animals exhibit decreased food intake and lower body weight compared to $C$ animals [29]. All RG analyses were made utilizing the PF group instead of the $\mathrm{C}$ group 
to account for any non-specific changes due to unequal food intake.

\section{BestKeeper analysis}

BestKeeper software analysis ranks RG based on a pairwise correlation and then calculates the most suitable RG based on geometric means assessing crossing points (CP) or Cq. Among potential RG examined, if the criterion (SDCq value < 1.0) was met, RG were considered suitable for qPCR normalization [27]. Interestingly, when analyzing RG in both experimental groups (PF and ID) in individual tissue, all RG except one exhibited stability based on the criteria (data not shown). Rplpo failed to meet the criteria in heart tissue $(\mathrm{SDCq}=1.2)$. After analyzing each experimental group individually using an all tissue combined approach, BestKeeper analyses indicated high variation in RG expression in the PF group with only Hprt meeting the criteria (Table 1) and moderate variation in the ID group with five of the candidate genes Hprt, Rps29, Tbp, Rpl19, and RplpO having an SDCq value $<1.0$ (Table 2). Finally, when combining datasets from all tissues and both experimental groups to determine which RG exhibits the least amount of variability, Hprt and Rpl19 displayed the most stability (Table 3). Interestingly, two commonly used RG in the rat model of ID and other nutrition models, Actb and Gapdh, exhibited poor stability with $A c t b$ having the least stability in all BestKeeper analyses [30-32].

\section{Comparative $\Delta \mathrm{Cq}$ analysis}

Gene expression levels were analyzed for stability using the comparative $\Delta \mathrm{Cq}$ method and standard deviations (SD) [22]. Pairwise comparisons were utilized to determine $\Delta \mathrm{Cq}$ of the relative gene expression within individual tissues and in all tissues combined. Mean $\Delta \mathrm{Cq}$ and SD were then averaged to interpret RG stability values for each experimental condition individually (PF and ID) and combined experimental conditions stability among all tissues. Similar to Silver et al.'s results, certain genes exhibited increased or decreased levels of deviation in $\Delta \mathrm{Cq}$ among all tissues and experimental condition analyses [22]. Those genes calculated to have the lowest mean SD were interpreted as having the most stability as a RG. After examining treatment conditions separately, Rpl22 and Hprt exhibited the most stability in PF animals and Rpl19 and Ppia exhibited the most stability in ID animals. Finally, when combining datasets from each tissue and both experimental groups to determine which RG exhibits the most stability, Rpl19 and Actb had the lowest mean SD and therefore the most stability, while RplpO and Ppia had the highest SD or least stability (Table 4).

\section{NormFinder analysis}

In contrast to the BestKeeper software, NormFinder determines suitability of RG as a function of variability. NormFinder software ranks potential RG using a model-based approach. The methodology examines sample subgroups (PF and ID herein), disparity in intra- and intergroup expression, and from these data calculates a stability value for candidate RG [2]. RG were assessed first in each tissue individually and then in all tissues combined to determine appropriateness of a single RG for use in all tissues. Among individual tissues, the most stable RG were Rps29 in the heart, $T b p$ in the kidney and lung, Rpl27 in the liver, and Ppia in the gastrocnemius and spleen. Exhibiting the least stability, Actb ranked poorly in nearly all tissues (Fig. 1A-F). After combining data from the six individual tissues, Rps29 and Rpl27 were identified as the most stable RG and Hprt and Gapdh as the least stable RG using NormFinder (Fig. 2).

Table 1 BestKeeper descriptive statistics and ranking of reference genes in pair-fed iron-replete animals in all tissues

\begin{tabular}{|c|c|c|c|c|c|c|c|c|c|c|}
\hline & Hprt & Rps29 & Rplpo & Tbp & Rp/27 & Rp/22 & Gapdh & Actb & Ppia & Rp/19 \\
\hline Geo mean $[C P]$ & 22.68 & 17.72 & 19.08 & 24.32 & 18.3 & 17.89 & 17.92 & 17.13 & 19.89 & 22.72 \\
\hline CV & 0.02 & 0.06 & 0.06 & 0.05 & 0.06 & 0.06 & 0.07 & 0.07 & 0.06 & 0.06 \\
\hline Min [CP] & 21.28 & 15.75 & 17.05 & 22.54 & 15.77 & 15.87 & 16.13 & 14.85 & 17.79 & 19.52 \\
\hline $\operatorname{Max}[C P]$ & 24.66 & 20.73 & 22.36 & 26.45 & 21.15 & 20.38 & 20.65 & 19.9 & 25.65 & 25.29 \\
\hline Std dev $[ \pm \mathrm{CP}]$ & 0.51 & 1.06 & 1.08 & 1.11 & 1.13 & 1.14 & 1.17 & 1.22 & 1.24 & 1.37 \\
\hline $\operatorname{Min}[x$-fold $]$ & -2.64 & -3.92 & -4.08 & -3.45 & -5.78 & -4.04 & -3.46 & -4.85 & -4.27 & -9.18 \\
\hline $\operatorname{Max}[x$-fold $]$ & 3.94 & 8.05 & 9.71 & 4.37 & 7.21 & 5.64 & 6.63 & 6.85 & 54.44 & 5.92 \\
\hline Std dev [ $\pm x$-fold] & 1.42 & 2.08 & 2.11 & 2.16 & 2.19 & 2.2 & 2.25 & 2.33 & 2.37 & 2.59 \\
\hline Ranking & 1 & 2 & 3 & 4 & 5 & 6 & 7 & 8 & 9 & 10 \\
\hline
\end{tabular}

Geometric mean (CP), coefficient of variance (CV), and standard deviation ( $\pm \mathrm{CP}$ ) of the Cq values for putative reference genes. RG are ordered from left to right according to their $\mathrm{SD}_{\mathrm{Cq}}$ value. Reference genes with a $\mathrm{SD}_{\mathrm{Cq}}$ value $<1.0$ are considered to be an appropriate reference gene when assessing gene expression in the pair-fed animals. To determine the under- and over-expression of a reference gene relative to the gene's geometric mean ( $x$-fold), the min, max, and standard deviation are calculated by the BestKeeper software 
Table 2 BestKeeper descriptive statistics and ranking of reference genes in iron-deficient animals in all tissues

\begin{tabular}{|c|c|c|c|c|c|c|c|c|c|c|}
\hline & Hprt & Rps29 & $T b p$ & Rpl19 & Rplpo & Ppia & Rpl27 & Rp/22 & Actb & Gapdh \\
\hline Geo mean $[C P]$ & 22.57 & 17.48 & 24.16 & 17.44 & 19.2 & 17.6 & 18.8 & 17.99 & 16.64 & 22.47 \\
\hline CV & 0.03 & 0.05 & 0.04 & 0.05 & 0.05 & 0.06 & 0.06 & 0.06 & 0.07 & 0.07 \\
\hline Min $[C P]$ & 21.13 & 15.55 & 21.67 & 15.45 & 17.26 & 15.48 & 16.62 & 15.68 & 14.49 & 19.18 \\
\hline $\operatorname{Max}[C P]$ & 24.39 & 18.96 & 25.7 & 18.51 & 20.59 & 19.05 & 20.78 & 19.59 & 18.16 & 25.85 \\
\hline Std dev $[ \pm C P]$ & 0.64 & 0.89 & 0.91 & 0.93 & 0.94 & 1.01 & 1.06 & 1.08 & 1.14 & 1.48 \\
\hline $\operatorname{Min}[x$-fold] & -2.7 & -3.81 & -5.6 & -3.98 & -3.83 & -4.35 & -4.53 & -4.95 & -4.42 & -9.75 \\
\hline $\operatorname{Max}[x$-fold $]$ & 3.55 & 2.79 & 2.91 & 2.11 & 2.62 & 2.73 & 3.95 & 3.02 & 2.88 & 10.4 \\
\hline Std dev $[ \pm x$-fold $]$ & 1.56 & 1.86 & 1.88 & 1.9 & 1.92 & 2.01 & 2.09 & 2.12 & 2.2 & 2.8 \\
\hline Ranking & 1 & 2 & 3 & 4 & 5 & 6 & 7 & 8 & 9 & 10 \\
\hline
\end{tabular}

Geometric mean $(C P)$, coefficient of variance $(C V)$, and standard deviation $( \pm C P)$ of the Cq values for putative reference genes. $R G$ are ordered from left to right according to their $\mathrm{SD}_{\mathrm{Cq}}$ value. Reference genes with a $\mathrm{SD}_{\mathrm{Cq}}$ value $<1.0$ are considered to be an appropriate reference gene when assessing gene expression in the iron-deficient animals. To determine the under- and over-expression of a reference gene relative to the gene's geometric mean ( $x$-fold), the min, max, and standard deviation are calculated by the BestKeeper software

\section{RefFinder analysis}

RefFinder is a software program that utilizes multiple established algorithms (BestKeeper, $\Delta \mathrm{Cq}$, geNorm, and NormFinder) to calculate a comprehensive RG stability value [33]. Each gene is assigned a weight based on each algorithm's geometric mean and weights are then combined to conclude the overall RefFinder ranking. In the individual tissues, the most stable RG were Hprt in the heart, Rps29 in the kidney, RplpO in the lung, Rpl27 in the liver, and Ppia in the gastrocnemius and spleen (Fig. 3A-F). After combining the six tissues, Rpl19 and Rps 29 were identified as the most stable RG and Ppia and Gapdh as the least stable (Fig. 4). Interestingly, when experimental conditions were analyzed separately (PF or ID) and combined (PF and ID), Actb, Ppia, and Gapdh all were ranked in the bottom half respectively (data not shown).

Results from BestKeeper, comparative delta Cq, NormFinder, and RefFinder computational programs were organized to develop a relative overall ranking. The ranking was based on PF and ID experimental groups and all tissues combined. The top two candidates (in rank order of most suitable to least suitable) were Rpl19 and Rps29. The least suitable candidate was Gapdh, with $A c t b$, Ppia, and RplpO ranking second in a three-way tie (Table 5). The same analyses were completed for the top two candidates or most suitable genes in each specific tissue (Table 6).

Lastly, to compare the impact of RG on target gene abundance and the interpretation of data, Tfrc gene expression in the liver of PF and ID animals was examined. Using the two best RG based on the overall ranking, (Rpl19 and Rps29), and two commonly used genes that ranked poorly in our analyses (Gapdh and Ppia), the relative abundance of Tfrc mRNA was determined using the ddCt method [34]. Although Tfrc expression increased significantly in ID animals regardless of the RG utilized, the relative fold changes varied (Fig. 5) $(p<$

Table 3 BestKeeper descriptive statistics and ranking of reference genes in iron-replete and iron-deficient animals in all tissues

\begin{tabular}{|c|c|c|c|c|c|c|c|c|c|c|}
\hline & Hprt & Rpl19 & Rps29 & $T b p$ & Rpl27 & Rplpo & Ppia & Rpl22 & Actb & Gapdh \\
\hline Geo mean $[C P]$ & 22.62 & 17.58 & 17.69 & 24.24 & 18.94 & 19.55 & 17.76 & 18.15 & 16.89 & 22.60 \\
\hline CV & 0.03 & 0.06 & 0.06 & 0.04 & 0.06 & 0.06 & 0.06 & 0.06 & 0.07 & 0.06 \\
\hline Min $[C P]$ & 21.13 & 15.45 & 15.55 & 21.67 & 16.62 & 17.26 & 15.48 & 15.68 & 14.49 & 19.18 \\
\hline $\operatorname{Max}[C P]$ & 24.66 & 20.73 & 20.38 & 26.45 & 22.36 & 25.65 & 20.65 & 21.15 & 19.90 & 25.85 \\
\hline Std dev $[ \pm C P]$ & 0.58 & 0.99 & 1.00 & 1.01 & 1.06 & 1.10 & 1.10 & 1.11 & 1.18 & 1.43 \\
\hline Min [x-fold] & -2.81 & -4.39 & -4.39 & -5.94 & -5.00 & -4.88 & -4.86 & -5.52 & -5.26 & -10.66 \\
\hline $\operatorname{Max}[x$-fold] & 4.10 & 8.85 & 6.47 & 4.62 & 10.67 & 68.84 & 7.38 & 8.00 & 8.10 & 9.52 \\
\hline Std dev $[ \pm x$-fold $]$ & 1.49 & 1.99 & 2.00 & 2.01 & 2.08 & 2.14 & 2.15 & 2.16 & 2.27 & 2.70 \\
\hline Ranking & 1 & 2 & 3 & 4 & 5 & 6 & 7 & 8 & 9 & 10 \\
\hline
\end{tabular}

Geometric mean (CP), coefficient of variance (CV), and standard deviation ( \pm CP) of the Cq values for putative reference genes. RG are ordered from left to right according to their $\mathrm{SD}_{\mathrm{Cq}}$ value. Reference genes with a $\mathrm{SD}_{\mathrm{Cq}}$ value $<1.0$ are considered to be an appropriate reference gene when assessing gene expression in pair-fed and iron-deficient animals. To determine the under- and over-expression of a reference gene relative to the gene's geometric mean ( $x$-fold), the min, max, and standard deviation are calculated by the BestKeeper software 
Table 4 Comparative $\Delta C q$ evaluation and ranking of RG in pair-fed and iron-deficient animals in all tissues

\begin{tabular}{|c|c|c|c|c|c|c|c|c|c|c|c|c|c|c|c|}
\hline Sample & $\begin{array}{l}\text { Mean } \\
\Delta C q\end{array}$ & SD & $\begin{array}{l}\text { Mean } \\
\text { SD }\end{array}$ & Sample & $\begin{array}{l}\text { Mean } \\
\Delta C q\end{array}$ & SD & $\begin{array}{l}\text { Mean } \\
\text { SD }\end{array}$ & Sample & $\begin{array}{l}\text { Mean } \\
\Delta C q\end{array}$ & SD & $\begin{array}{l}\text { Mean } \\
\text { SD }\end{array}$ & Sample & $\begin{array}{l}\text { Mean } \\
\Delta \mathrm{Cq}\end{array}$ & SD & $\begin{array}{l}\text { Mean } \\
\text { SD }\end{array}$ \\
\hline $\begin{array}{l}\text { Rp/19 vs } \\
\text { Actb }\end{array}$ & -0.700 & 0.280 & 0.400 & $\begin{array}{l}\text { Tbp vs } \\
\text { Actb }\end{array}$ & -7.410 & 0.250 & 0.440 & $\begin{array}{l}\text { Rps } 29 \text { vs } \\
\text { Rpl27 }\end{array}$ & 1.460 & 0.400 & 0.590 & $\begin{array}{l}\text { Rplpo vs } \\
\text { Gapdh }\end{array}$ & 2.110 & 0.650 & 1.450 \\
\hline $\begin{array}{l}\text { Rpl19 vs } \\
\text { Rpl27 }\end{array}$ & 1.430 & 0.280 & (1) & $\begin{array}{l}\text { Tbp vs } \\
\text { Rpl27 }\end{array}$ & -6.070 & 0.250 & (4) & $\begin{array}{l}\text { Rps } 29 \text { vs } \\
\text { Rpl19 }\end{array}$ & 0.030 & 0.420 & (7) & $\begin{array}{l}\text { Rplpo vs } \\
\text { Rpl19 }\end{array}$ & -1.930 & 0.660 & (10) \\
\hline $\begin{array}{l}\text { Rp/19 vs } \\
\text { Rpl22 }\end{array}$ & 0.630 & 0.290 & & $\begin{array}{l}\text { Tbp vs } \\
\text { Hprt }\end{array}$ & -2.240 & 0.280 & & $\begin{array}{l}\text { Rps } 29 \text { vs } \\
\text { Ppia }\end{array}$ & 0.440 & 0.510 & & $\begin{array}{l}\text { Rplpo vs } \\
\text { Ppia }\end{array}$ & -1.590 & 0.720 & \\
\hline $\begin{array}{l}\text { Rpl19 vs } \\
\text { Ppia }\end{array}$ & 0.340 & 0.310 & & $\begin{array}{l}\text { Tbp vs } \\
\text { Ppia }\end{array}$ & -6.380 & 0.310 & & $\begin{array}{l}\text { Rps } 29 \text { vs } \\
\text { Rpl27 }\end{array}$ & 0.740 & 0.550 & & $\begin{array}{l}\text { Rplpo vs } \\
\text { Act }\end{array}$ & -2.620 & 0.740 & \\
\hline $\begin{array}{l}\text { Rp/19 vs } \\
\text { Tbp }\end{array}$ & 6.700 & 0.360 & & $\begin{array}{l}\text { Tbp vs } \\
\text { Rpl19 }\end{array}$ & -6.700 & 0.360 & & $\begin{array}{l}\text { Rps } 29 \text { vs } \\
\text { Actb }\end{array}$ & -0.590 & 0.600 & & $\begin{array}{l}\text { Rplpo vs } \\
\text { Hprt }\end{array}$ & 2.050 & 0.910 & \\
\hline $\begin{array}{l}\text { Rpl19 vs } \\
\text { Rps29 }\end{array}$ & -0.030 & 0.420 & & $\begin{array}{l}\text { Top vs } \\
\text { Rpl27 }\end{array}$ & -5.280 & 0.360 & & $\begin{array}{l}\text { Rps } 29 \text { vs } \\
\text { Tbp }\end{array}$ & 6.820 & 0.650 & & $\begin{array}{l}\text { Rplp0 vs } \\
\text { Rps29 }\end{array}$ & -2.650 & 2.080 & \\
\hline $\begin{array}{l}\text { Rpl19 vs } \\
\text { Hprt }\end{array}$ & 4.460 & 0.510 & & $\begin{array}{l}\text { Tbp vs } \\
\text { Rps29 }\end{array}$ & -6.820 & 0.650 & & $\begin{array}{l}\text { Rps } 29 \text { vs } \\
\text { Hprt }\end{array}$ & 4.570 & 0.680 & & $\begin{array}{l}\text { Rplpo vs } \\
\text { Rpl27 }\end{array}$ & -1.210 & 2.140 & \\
\hline $\begin{array}{l}\text { Rpl19 vs } \\
\text { Gapdh }\end{array}$ & 4.030 & 0.540 & & $\begin{array}{l}\text { Tbp vs } \\
\text { Gapdh }\end{array}$ & -2.680 & 0.660 & & $\begin{array}{l}\text { Rps29 vs } \\
\text { Gapdh }\end{array}$ & 4.140 & 0.740 & & $\begin{array}{l}\text { Rplpo vs } \\
\text { Rpl22 }\end{array}$ & -1.880 & 2.290 & \\
\hline $\begin{array}{l}\text { Rpl19 vs } \\
\text { Rplpo }\end{array}$ & 1.930 & 0.660 & & $\begin{array}{l}\text { Tbp vs } \\
\text { Rplpo }\end{array}$ & -4.790 & 0.840 & & $\begin{array}{l}\text { Rps29 vs } \\
\text { Rplp0 }\end{array}$ & 2.030 & 0.750 & & $\begin{array}{l}\text { Rplpo vs } \\
\text { Tbp }\end{array}$ & 3.990 & 2.850 & \\
\hline $\begin{array}{l}\text { Actb vs } \\
\text { Tbp }\end{array}$ & 7.410 & 0.250 & 0.420 & $\begin{array}{l}\text { Rpl22 vs } \\
\text { Rpl27 }\end{array}$ & 0.800 & 0.240 & 0.450 & $\begin{array}{l}\text { Gapdh vs } \\
\text { Rpl19 }\end{array}$ & -4.030 & 0.540 & 0.630 & & & & \\
\hline $\begin{array}{l}\text { Actb vs } \\
\text { Rpl19 }\end{array}$ & 0.700 & 0.280 & (2) & $\begin{array}{l}\text { Rpl22 vs } \\
\text { Tbp }\end{array}$ & 6.070 & 0.250 & (5) & $\begin{array}{l}\text { Gapdh vs } \\
\text { Actb }\end{array}$ & -4.730 & 0.560 & (8) & & & & \\
\hline $\begin{array}{l}\text { Actb vs } \\
\text { Ppia }\end{array}$ & 1.030 & 0.290 & & $\begin{array}{l}\text { Rpl22 vs } \\
\text { Ppia }\end{array}$ & -0.310 & 0.290 & & $\begin{array}{l}\text { Gapdh vs } \\
\text { Rpl27 }\end{array}$ & -2.600 & 0.590 & & & & & \\
\hline $\begin{array}{l}\text { Actb vs } \\
\text { Rpl22 }\end{array}$ & 1.330 & 0.320 & & $\begin{array}{l}\text { Rpl22 vs } \\
\text { Rpl19 }\end{array}$ & -0.630 & 0.290 & & $\begin{array}{l}\text { Gapdh vs } \\
\text { Ppia }\end{array}$ & -3.700 & 0.620 & & & & & \\
\hline $\begin{array}{l}\text { Actb vs } \\
\text { Rpl27 }\end{array}$ & 2.120 & 0.390 & & $\begin{array}{l}\text { Rpl22 vs } \\
\text { Hprt }\end{array}$ & 3.830 & 0.390 & & $\begin{array}{l}\text { Gapdh vs } \\
\text { Hprt }\end{array}$ & 0.430 & 0.630 & & & & & \\
\hline $\begin{array}{l}\text { Actb vs } \\
\text { Hprt }\end{array}$ & 5.160 & 0.410 & & $\begin{array}{l}\text { Rpl22 vs } \\
\text { Actb }\end{array}$ & -0.870 & 0.460 & & $\begin{array}{l}\text { Gapdh vs } \\
\text { Rplpo }\end{array}$ & -2.110 & 0.650 & & & & & \\
\hline $\begin{array}{l}\text { Actb vs } \\
\text { Gapdh }\end{array}$ & 4.730 & 0.560 & & $\begin{array}{l}\text { Rpl22 vs } \\
\text { Rps } 29\end{array}$ & -0.740 & 0.550 & & $\begin{array}{l}\text { Gapdh vs } \\
\text { Rpl22 }\end{array}$ & -3.400 & 0.650 & & & & & \\
\hline $\begin{array}{l}\text { Actb vs } \\
\text { Rps29 }\end{array}$ & 0.590 & 0.600 & & $\begin{array}{l}\text { Rpl22 vs } \\
\text { Gapdh }\end{array}$ & 3.400 & 0.650 & & $\begin{array}{l}\text { Gapdh vs } \\
\text { Tbp }\end{array}$ & 2.680 & 0.660 & & & & & \\
\hline $\begin{array}{l}\text { Actb vs } \\
\text { Rplpo }\end{array}$ & 2.620 & 0.740 & & $\begin{array}{l}\text { Rpl22 vs } \\
\text { Rplpo }\end{array}$ & 1.750 & 0.910 & & $\begin{array}{l}\text { Gapdh vs } \\
\text { Rps29 }\end{array}$ & -4.140 & 0.740 & & & & & \\
\hline $\begin{array}{l}\text { Rpl22 vs } \\
\text { Rpl27 }\end{array}$ & -0.800 & 0.240 & 0.430 & $\begin{array}{l}\text { Hprt vs } \\
\text { Tbp }\end{array}$ & 2.240 & 0.280 & 0.530 & $\begin{array}{l}\text { Ppia vs } \\
\text { Actb }\end{array}$ & -1.030 & 0.290 & 1.180 & & & & \\
\hline $\begin{array}{l}\text { Rpl27 vs } \\
\text { Rpl19 }\end{array}$ & -1.430 & 0.280 & (3) & $\begin{array}{l}\text { Hprt vs } \\
\text { Rpl22 }\end{array}$ & -3.830 & 0.390 & (6) & $\begin{array}{l}\text { Ppia vs } \\
\text { Rpl19 }\end{array}$ & -0.340 & 0.310 & (9) & & & & \\
\hline $\begin{array}{l}\text { Rpl27 vs } \\
\text { Top }\end{array}$ & 5.280 & 0.360 & & $\begin{array}{l}\text { Hprt vs } \\
\text { Ppia }\end{array}$ & -4.140 & 0.420 & & $\begin{array}{l}\text { Ppia vs } \\
\text { Hprt }\end{array}$ & 4.140 & 0.420 & & & & & \\
\hline $\begin{array}{l}\text { Rpl27 vs } \\
\text { Ppia }\end{array}$ & -1.090 & 0.370 & & $\begin{array}{l}\text { Hprt vs } \\
\text { Actb }\end{array}$ & -5.170 & 0.490 & & $\begin{array}{l}\text { Ppia vs } \\
\text { Gapdh }\end{array}$ & 3.700 & 0.620 & & & & & \\
\hline $\begin{array}{l}\text { Rpl27 vs } \\
\text { Actb }\end{array}$ & -2.120 & 0.390 & & $\begin{array}{l}\text { Hprt vs } \\
\text { Rpl27 }\end{array}$ & -3.030 & 0.500 & & $\begin{array}{l}\text { Ppia vs } \\
\text { Rplpo }\end{array}$ & 1.570 & 0.720 & & & & & \\
\hline $\begin{array}{l}\text { Rpl27 vs } \\
\text { Rps } 29\end{array}$ & -1.460 & 0.400 & & $\begin{array}{l}\text { Hprt vs } \\
\text { Rpl19 }\end{array}$ & -4.460 & 0.510 & & $\begin{array}{l}\text { Ppia vs } \\
\text { Rpl22 }\end{array}$ & -0.290 & 1.870 & & & & & \\
\hline $\begin{array}{l}\text { Rpl27 vs } \\
\text { Hprt }\end{array}$ & 3.030 & 0.500 & & $\begin{array}{l}\text { Hprt vs } \\
\text { Gapdh }\end{array}$ & -0.430 & 0.630 & & $\begin{array}{l}\text { Ppia vs } \\
\text { Rps } 29\end{array}$ & -1.060 & 1.880 & & & & & \\
\hline $\begin{array}{l}\text { Rpl27 vs } \\
\text { Gapdh }\end{array}$ & 2.600 & 0.590 & & $\begin{array}{l}\text { Hprt vs } \\
\text { Rps } 29\end{array}$ & -4.570 & 0.680 & & $\begin{array}{l}\text { Ppia vs } \\
\text { Rpl27 }\end{array}$ & 0.370 & 2.120 & & & & & \\
\hline Rpl27 vs & 0.500 & 0.730 & & Hprt vs & -2.560 & 0.910 & & Ppia vs & 5.580 & 2.400 & & & & & \\
\hline
\end{tabular}


Table 4 Comparative $\Delta C q$ evaluation and ranking of $R G$ in pair-fed and iron-deficient animals in all tissues (Continued)

\begin{tabular}{|c|c|c|c|c|c|c|c|c|c|c|c|c|c|c|c|}
\hline Sample & $\begin{array}{l}\text { Mean } \\
\Delta \mathrm{Cq}\end{array}$ & SD & $\begin{array}{l}\text { Mean } \\
\text { SD }\end{array}$ & Sample & $\begin{array}{l}\text { Mean } \\
\Delta C q\end{array}$ & SD & $\begin{array}{l}\text { Mean } \\
\text { SD }\end{array}$ & Sample & $\begin{array}{l}\text { Mean } \\
\Delta \mathrm{Cq}\end{array}$ & SD & $\begin{array}{l}\text { Mean } \\
\text { SD }\end{array}$ & Sample & $\begin{array}{l}\text { Mean } \\
\Delta C_{q}\end{array}$ & SD & $\begin{array}{l}\text { Mean } \\
\text { SD }\end{array}$ \\
\hline RplpO & & & & Rplpo & & & & Top & & & & & & & \\
\hline
\end{tabular}

Mean $\Delta \mathrm{Cq}$ values are given for the mean difference between the genes. Standard deviations (SD) are given for the variation in Cq values over the animals

0.05). For normalization using Rpl19 and Rps29 as RG, Tfrc mRNA abundance increased 10-fold and 8-fold in ID animals, respectively (Fig. 5). In contrast to the best ranking RG, using Gapdh and Ppia as RG, Tfrc mRNA abundance increased 6-fold and 7-fold, respectively (Fig. $5)$.

\section{Discussion}

The necessity for ensuring suitable RG in qPCR quantitation has been well recognized [2, 20, 26, 35, 36]. Ideal RG should exhibit minimal variation in expression levels among various tissues and under experimental manipulations [35]. The existence of an ideal RG is, however, uncertain at best. To date, limited data has been published on gene expression analyses with nutrient-gene interactions in animal models $[37,38]$ and to our knowledge, an empirical determination of appropriate RG selection in the male weanling rat model of iron deficiency has not been conducted. Additionally, the extent to which RG vary among specific tissues in the same nutritional model has not been examined.
This study was designed to evaluate variation in gene expression in ten commonly used RG in varying dietary (PF and ID) conditions and to identify the RG most suitable for iron deficiency analyses utilizing qPCR in gastrocnemius, heart, kidney, liver, lung, and spleen tissues. Our data is consistent with other research and suggests that commonly used RG may be regulated under experimental conditions and expression stability varies between tissues [26]. It is evident that appropriateness of a RG is likely dependent on the tissue of interest in which gene expression is being analyzed. For example, Gapdh ranked poorly in the majority of the computational programs, both in individual tissues and when combining all tissues for analysis. However, NormFinder and RefFinder data concluded Gapdh had increased stability and was ranked in the top 3 RG in skeletal muscle. Another example of RG inconsistency based on tissue occurred with $R p l p O$; although $R p l p O$ is one of the least stable RG in the liver, it is the most stable RG in the lung based on the RefFinder results. These tissue differences were reflected in poor overall ranking when all

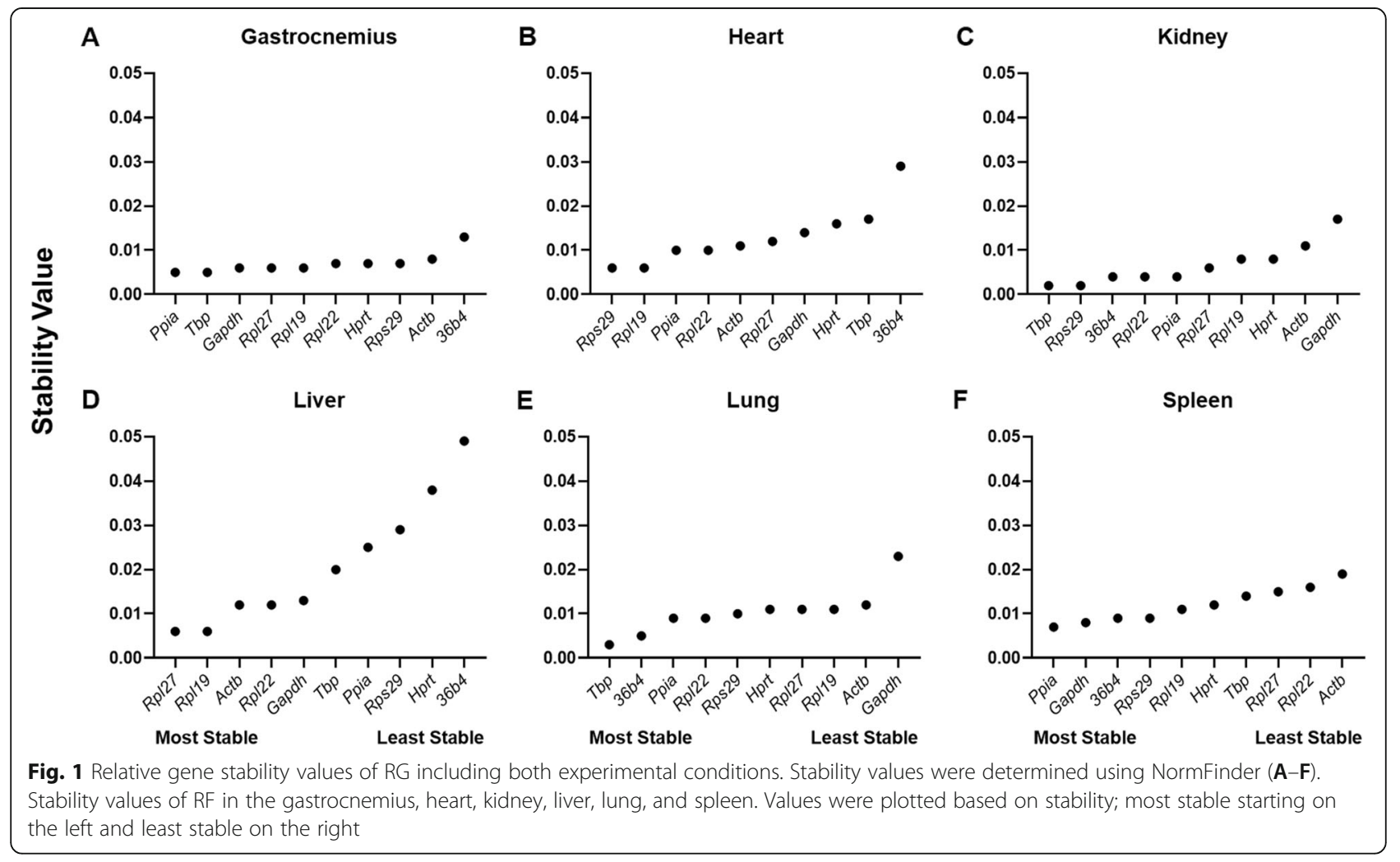




\section{All tissue}

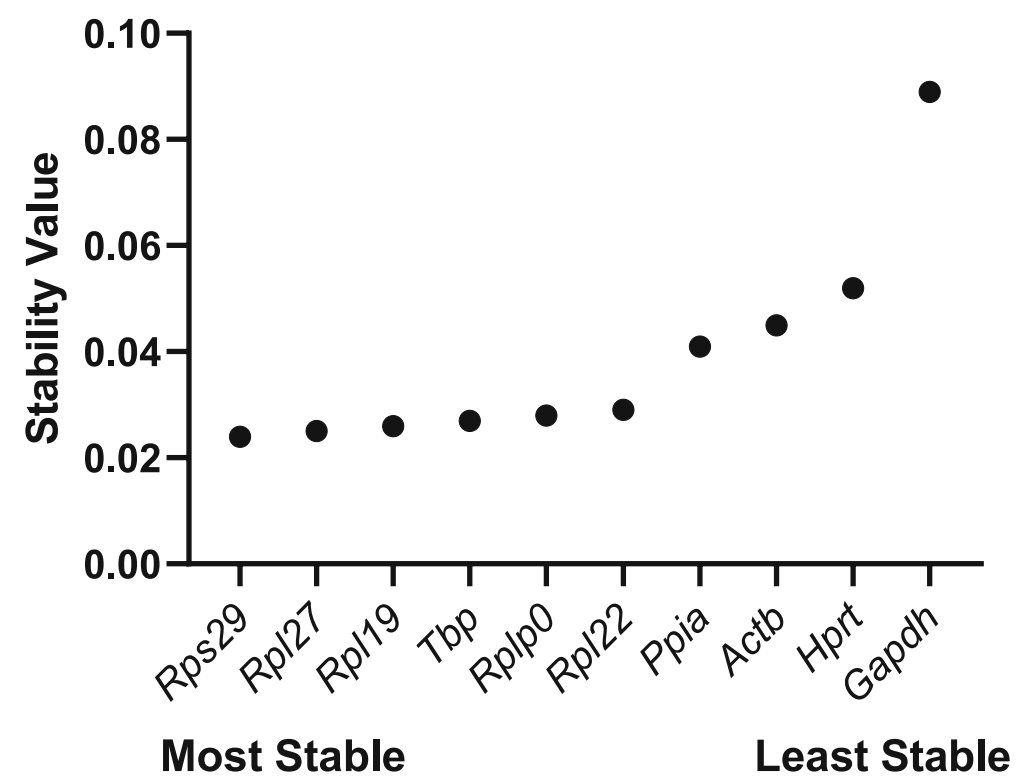

Fig. 2 Relative gene stability values of RG. Stability values were determined using NormFinder. Stability values of reference genes based on a combined analysis of gene expression in the gastrocnemius, heart, kidney, liver, lung, and spleen. Values were plotted based on stability; most stable starting on the left and least stable on the right

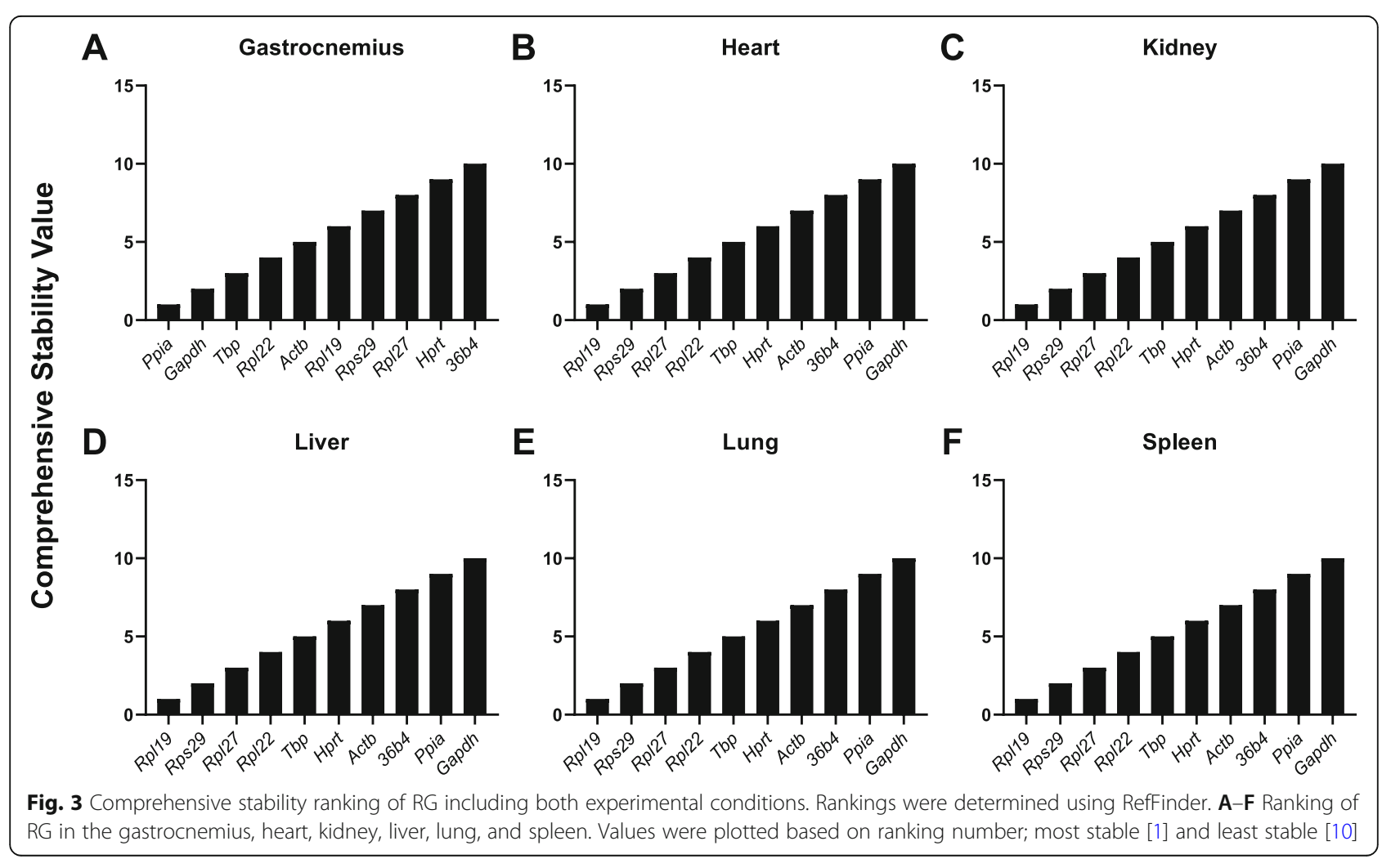




\section{All tissues}

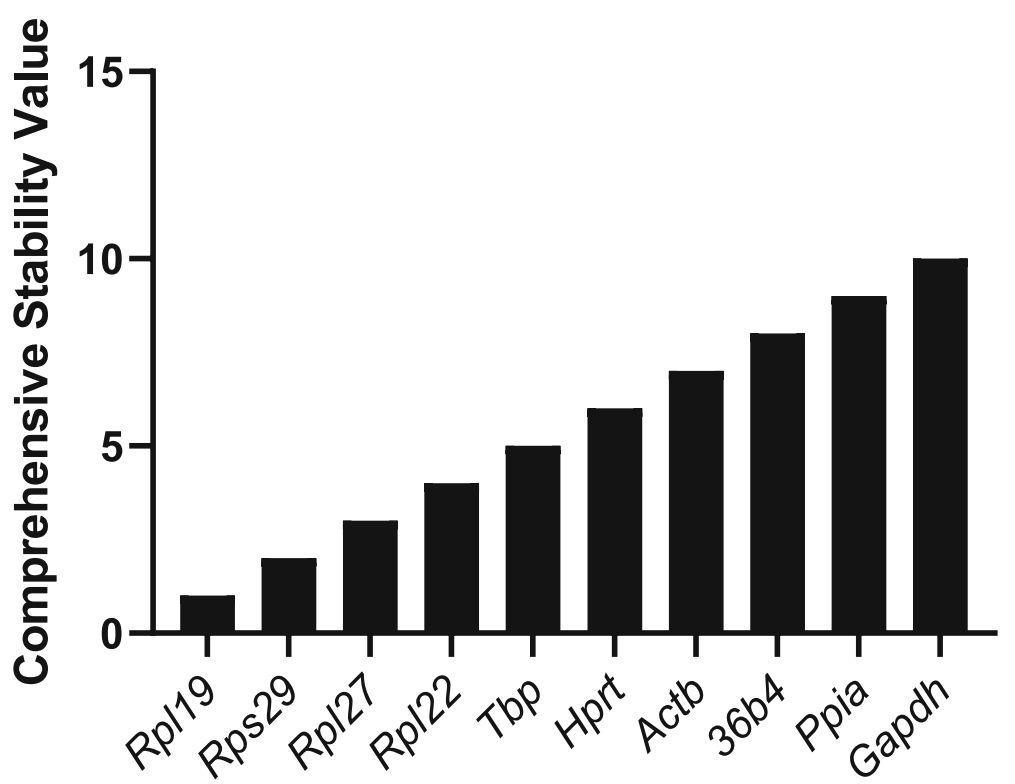

Fig. 4 Comprehensive stability ranking of RG including both experimental conditions. Rankings were determined using RefFinder. Ranking of RG was based on a combined analysis of gene expression in the gastrocnemius, heart, kidney, liver, lung, and spleen. Values were plotted based on ranking number; most stable [1] and least stable [10]

tissues were combined for analysis. In contrast, both Rpl19 and Rps29 were relatively stable in all tissues resulting in a high overall ranking as determined by all software analyses and our combined overall ranking system. Thus, it is evident that appropriateness of a RG is likely dependent on the tissue of interest in which gene expression is being analyzed, and when comparing multiple tissues simultaneously, it is important RG exhibit relative stability across all tissues.

The RG selected herein have diverse biological functions and origination. The RG can be categorized as encoding for (1) ribosomal proteins, (2) structural proteins, or (3) enzymatic proteins (Table 7). Based on our results, rRNA (Rpl19 and Rps29) are the most stable and highest ranking RG for the weanling model of iron deficiency. Although ribosomal RG tend to be more stable in our study, it is important to understand the limitations of using rRNA as RG. First, synthesis of rRNA (RNA polymerase I) and mRNA (RNA polymerase II) are independent, and for that reason, it is thought to be controversial to choose a RG whose transcription is not regulated in the same manner [39]. Second, if original RNA samples were enriched for mRNA, rRNA would be excluded from the isolation process making it an inappropriate control [16]. The samples used in this study were not enriched for any RNA species as evidenced by agarose gel. Next, according to Derveaux et al. [40], it is important to select RG with a similar abundance level to the target mRNA (or gene), making rRNA unsuitable since they are expressed at much higher levels than mRNA. Finally, like mRNA, rRNA have been reported to be regulated under some experimental conditions [20, $41,42]$.

The use of computational programs for determination of the most suitable RG assumes consistent gene expression profiles between experimental groups. Our study,

Table 5 Relative overall ranking

\begin{tabular}{lllllll}
\hline & Ranking & BestKeeper & $\Delta$ Cq & NormFinder & RefFinder & Overall \\
\hline Most stable & 1 & Hprt & Rpl19 & Rps29 & Rp/19 & Rp/19 \\
& 2 & Rpl19 & Actb & Rpl27 & Rps29 29 & Gapdh \\
Least stable & 1 & Gapdh & Rplp0 & Gapdh & Gapdh & Ppia \\
& 2 & Actb & Ppia & Hprt & Ppia \\
\hline
\end{tabular}

The two most stable and two least stable RG from BestKeeper, comparative $\Delta$ Cq, NormFinder, and RefFinder were combined to provide an overall ranking of PF and ID experimental groups in all tissues. Overall ranking was determined by quantifying the most stable or least stable genes of all programs 
Table 6 Relative overall ranking for each tissue

\begin{tabular}{|c|c|c|c|c|c|c|}
\hline Gastrocnemius & Ranking & BestKeeper & $\Delta \mathrm{Cq}$ & NormFinder & RefFinder & Overall \\
\hline \multirow[t]{2}{*}{ Most stable } & 1 & Gapdh & Ppia & Ppia & Ppia & Ppia \\
\hline & 2 & Ppia & Rpl22 & Top & Gapdh & Gapdh \\
\hline Heart & Ranking & BestKeeper & $\Delta \mathrm{Cq}$ & NormFinder & RefFinder & Overall \\
\hline \multirow[t]{2}{*}{ Most stable } & 1 & Hprt & $\operatorname{Rps} 29$ & $\operatorname{Rps} 29$ & Hprt & Rps29 \\
\hline & 2 & Top & Rp/19 & Rp/19 & Rps29 & Rp/19/Hprt* \\
\hline Kidney & Ranking & BestKeeper & $\Delta \mathrm{Cq}$ & NormFinder & RefFinder & Overall \\
\hline \multirow[t]{2}{*}{ Most stable } & 1 & Gapdh & Ppia & Top & Rps29 & $\operatorname{Rps} 29$ \\
\hline & 2 & $36 b 4$ & $36 b 4$ & Rps29 & Rpl22 & $36 b 4$ \\
\hline Liver & Ranking & BestKeeper & $\Delta \mathrm{Cq}$ & NormFinder & RefFinder & Overall \\
\hline \multirow[t]{2}{*}{ Most stable } & 1 & Tbp & Rpl27 & Rpl27 & Rpl27 & Rpl27 \\
\hline & 2 & Rpl27 & Rpl19 & Rp/19 & Rpl19 & Rpl19 \\
\hline Lung & Ranking & BestKeeper & $\Delta \mathrm{Cq}$ & NormFinder & RefFinder & Overall \\
\hline \multirow[t]{2}{*}{ Most stable } & 1 & Gapdh & $36 b 4$ & $T b p$ & $36 b 4$ & $36 b 4^{*}$ \\
\hline & 2 & Hprt & $T b p$ & $36 b 4$ & Tbp & $T b p^{*}$ \\
\hline Spleen & Ranking & BestKeeper & $\Delta \mathrm{Cq}$ & NormFinder & RefFinder & Overall \\
\hline \multirow[t]{3}{*}{ Most stable } & 1 & $36 b 4$ & $\operatorname{Rps} 29$ & Ppia & Ppia & Gapdh* \\
\hline & 2 & Gapdh & Rpl22 & Gapdh & Rps29 & Ppia* \\
\hline & & & & & & $\operatorname{Rps} 29^{*}$ \\
\hline
\end{tabular}

The two most stable RG from BestKeeper, comparative $\Delta C$, NormFinder, and RefFinder were combined to provide an overall ranking of PF and ID experimental groups in gastrocnemius, heart, kidney, liver, lung, and spleen. Overall ranking for each tissue was determined by quantifying the most stable genes of all programs. *Indicates equal stability ranking

consistent with other studies, shows similar results in overall ranking between all computational programs for some genes [43, 44]. This could be due to overlap in computational programs as RefFinder uses a combination of NormFinder, BestKeeper, Delta CT, and Genorm. We did not give more weight to any one program to take an unbiased approach to the analyses. Substantial variation was exhibited by some of the RG under examination. For instance, when analyzing all tissues together in both PF and ID animals, Actb ranked as the second most stable gene with the $\Delta \mathrm{Cq}$ method, but then ranked in the bottom half of all genes with BestKeeper, NormFinder, and RefFinder. Thus, this type of result supports a more robust approach to RG selection. Despite some

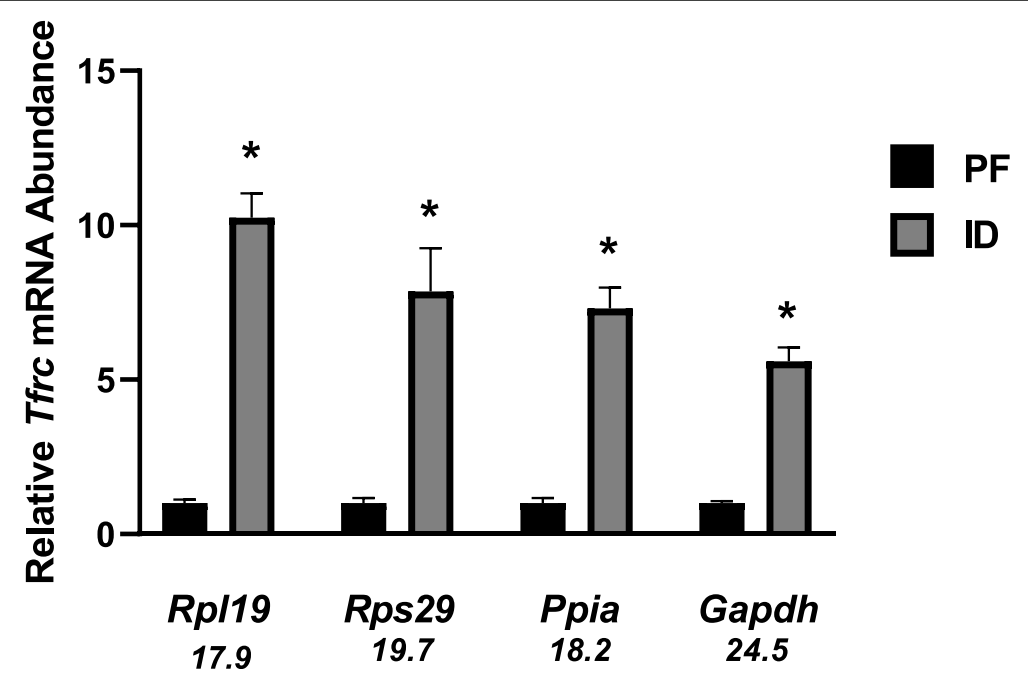

Fig. 5 Real-Time quantitative PCR results assessing relative Tfrc mRNA expression in the liver. The mRNA levels of Tfrcl were normalized to Rp/19, Rps29, Ppia, and Gapdh in pair-fed and iron-deficient rat livers 
Table 7 Reference gene information

\begin{tabular}{llll}
\hline Gene name & Gene symbol & Accession number & Function \\
\hline Actin, beta & Actb & NM_031144 & Cytoskeletal structural protein \\
Glyceraldehyde-3-phosphate dehydrogenase & Gapdh & NM_017008 & Glycolysis enzyme \\
Hypoxanthine phosphoribosyltransferase 1 & Hprt & NM_012583 & Salvages purines \\
Peptidylprolyl isomerase A (cyclophilin A) & Ppia & NM_017101 & Protein folding \\
Ribosomal protein L19 & Rpl19 & NM_031103 & Protein synthesis \\
Ribosomal protein L22 & Rpl22 & NM_031104 & Protein synthesis \\
Ribosomal protein L27 & Rpl27 & NM_022514 & Protein synthesis \\
Ribosomal protein, large, P0 (36b4) & Rplp0 & NM_022402 & Protein synthesis \\
Ribosomal protein S29 & Rps29 & NM_012876 & Protein synthesis \\
TATA box-binding protein & Tbp & NM_001004198 & RNA polymerase II transcription factor \\
\hline
\end{tabular}

similarities between computational program results, small differences in RG stability do exist and could lead to unreliable data interpretation. For instance, when liver Tfrc mRNA abundance levels were normalized to the most stable RG (Rpl19 and Rps29) and the least stable RG (Actb and Gapdh), as determined by our overall ranking system, Tfrc mRNA abundance was significantly increased in the ID animals based on all four RG; however, the magnitude of the differences varied. A significant increase in Tfrc mRNA abundance in response to dietary iron deficiency has been well established [45, 46], however in studies aiming to evaluate target mRNA that result in marginal mRNA abundance changes, a significance may not be detected. Therefore, it may be necessary to use multiple computational programs when determining the most stable RG for nutrient-gene interaction-focused studies. Additionally, as suggested by Bustin et al. [15], using more than one RG for normalization and choosing the top ranked RG based on the use of multiple computational programs is likely the superior comprehensive approach investigators should use for mRNA normalization.

\section{Conclusions}

Small changes in gene expression may be misinterpreted if an appropriate RG is not selected. Therefore, it may be inappropriate to choose RG for a study based solely on previous research or literature reviews instead of taking an empirical approach to identifying the most suitable RG. To our knowledge, this is the first study to examine RG stability for qPCR gene expression analyses focused on dietary condition and tissue type. Based on the ten-selected RG, Rpl19 and Rps29 are the most suitable RG for normalization studies involving gastrocnemius, heart, kidney, liver, lung, and spleen tissues in studies focused on the male weanling model of dietary iron deficiency. The combined ranking system provides a more appropriate evaluation of RG suitability because it provides a thorough assessment of overall RG stability based on four accepted computational RG programs. The model illustrated herein provides an appropriate method for validation of RG, specifically for studies involving dietary responses in multiple tissues, and should be implemented prior to qPCR assays in order to report valid and reliable results.

\section{Methods}

Twenty-one-day-old weanling male Sprague-Dawley (Harlan, Indianapolis, IN USA) rats $(n=24)$ were housed individually in stainless steel, wire-bottomed cages in an environmentally controlled facility and maintained on a 12-h light: dark cycle at $20{ }^{\circ} \mathrm{C}$ with ad libitum access to deionized water. All rats were allowed access to the control diet for 3 days prior to starting dietary treatments. Following the acclimation period, animals were randomly assigned to one of three diet groups ( $n=8$ per group) for 21 days: control iron-replete $(\mathrm{C} ; 40 \mathrm{mg} \mathrm{Fe} / \mathrm{kg}$ diet), pair-fed ironreplete (PF; control diet with the mean intake of the ID group) or iron-deficient (ID; $<5 \mathrm{mg} \mathrm{Fe} / \mathrm{kg}$ diet). Diets were purchased from Harlan Teklad (ENVIGO, Madison, WI, USA; C-TD.89300 and ID-TD.80396) based on the recommendations from the American Institute of Nutrition's 1976 (AIN 76) Standards for Nutritional Studies. Individual body weights and food intake were measured daily. Following the 21-day experimental period, animals were anesthetized with a ketamine/xylazine mixture and were sacrificed by exsanguination via the abdominal aorta. The gastrocnemius, heart, kidney, liver, lung, and spleen were snap-frozen in liquid nitrogen immediately following removal and stored at $-80{ }^{\circ} \mathrm{C}$ until subsequent analysis. All institutional guidelines for the care and use of laboratory animals were followed and approved by the OSU Institutional Animal Care and Use Committee. 
Table 8 Primer sequences for reference gene analysis by qPCR

\begin{tabular}{lll}
\hline Gene symbol & Forward primer & Reverse primer \\
\hline Actb & 5' CAT CGT GGG CCG CCC TA & 5' CGC CCA CGG AGG AGT CCT TCT G \\
Gapdh & 5' GAG GTG ACC GCA TCT TCT TG & 5' CCG ACC TTC ACC ATC TTG TC \\
Hprt & 5' GCC GAC CGG TTC TGT CAT & 5' CAT AAC CTG GTT CAT CAT CAC TAA TCA \\
Ppia & 5' GGT CTT TGG GAA GGT GAA AGA A & 5' GCC ATT CCT GGA CCC AAA A \\
Rpl19 & 5' CGT CCT CCG CTG TGG TAA A & 5' TGG CGA TT CGT TGG TाT \\
Rpl22 & 5' CAC CCT GTA GAA GAT GGA ATC ATG & 5' TTC CCG TTC ACC TTG ATC CT \\
Rpl27 & 5' GCA AAG CCG TCA TCG TAA AGA & 5' CTG GGA TAG CGG TCA ATT CC \\
Rplp0 & 5' TCC TCC GAC TCT TCC TT GC \\
Rps29 & 5' GCC AGG GTT CTC GCT CTT G & 5' GGC ACA TGT TCA GCC CGT AT \\
Tbp & 5' TGC CAG AAA TGC TGA ATA TAA TCC \\
Tfrc & 5' TCG GCT ACC TGG GCT ATT GT & 5' CCG GGC TCT CTT ATT CTC ATG CCG CTT CA
\end{tabular}

\section{RNA isolation and CDNA synthesis}

Total RNA was isolated from tissues including the gastrocnemius, heart, kidney, liver, lung, and spleen using STAT-60 (Tel-test, Inc., Friendswood, TX, USA) according to the manufacturer's instructions. After isolation, RNA concentration was determined using a Nanodrop spectrophotometer (Thermo Fisher Scientific, Waltham, MA, USA) and relative purity of total RNA was assessed by the $A_{260 / 280}$ ratio. Only $A_{260 / 280}$ ratios $\geq$ 1.8 were used for this study. The integrity of RNA was determined by examining $18 \mathrm{~S}$ and $28 \mathrm{~S}$ rRNA by agarose gel electrophoresis. Total RNA was treated with DNase I (Roche, Basel, Switzerland) and reverse-transcribed with SuperScript II (Invitrogen, Carlsbad, CA, USA) for a final cDNA concentration of $50 \mathrm{ng} / \mu \mathrm{L}$.

\section{Quantitative qPCR and data analysis}

Gene expression was determined by qPCR using SYBR Green chemistry on an ABI 7900HT sequence detection system instrument and 2.4 SDS software (Applied Biosystems, Foster City, CA, USA). All reactions were performed in $10 \mu \mathrm{L}$ volumes, including $50 \mathrm{ng}$ of template, $2.5 \mu \mathrm{M}$ of each forward and reverse primer, and $10 \mathrm{mM}$ of dNTPs ( $2.5 \mathrm{mM}$ each). Amplification was performed with a 2 min activation step at $50{ }^{\circ} \mathrm{C}, 10$ min denaturation step at $95{ }^{\circ} \mathrm{C}$, followed by 40 cycles of $90{ }^{\circ} \mathrm{C}$ for 15 $\mathrm{s}$ and $60^{\circ} \mathrm{C}$ for $1 \mathrm{~min}$. Following each cycle, a dissociation curve analysis was performed using the default settings of the software to confirm the specificity of the PCR products. For each target RG, the relative stability was assessed using BestKeeper, the comparative delta $\mathrm{Cq}$ $(\Delta \mathrm{Cq})$ method, NormFinder, and RefFinder.

RG were assessed in individual tissues and based on all tissues combined. They were assessed between experimental conditions (PF and ID) based on all tissues combined. Potential RG analyzed included Actb, Gapdh, Hprt, Ppia, Rpl19, Rpl22, Rpl27, Rplp0, Rps29, and Tbp (Table 7). The overall rankings were determined by using all tissue combined analyses or each specific tissue for each stability program. The two most stable and two least stable RG for each program were quantified based on the number of times they were ranked at the top or bottom. The two most stable and two least stable genes from the all tissues ranking were further used as RG to compare Tfrc gene expression in PF versus ID rat livers. The comparative $\Delta \Delta \mathrm{Cq}$ method was used to analyze mRNA abundance [47]. Oligonucleotide primers (Table 8) were obtained from Integrated DNA Technologies (IDT, Coralville, IA, USA) and designed using Primer Express software 3.0.1 (Applied Biosystems, Foster City, CA, USA). Briefly, nucleotide sequences were acquired from NCBI and primers were designed to cross exons, not exceed an amplicon length of 100 nucleotides, and have the lowest possible error rate.

\section{Statistical analysis}

Analyses were performed using SPSS version 23.0 software (IBM Corp., Armonk, NY, USA). Statistical analyses using Student's $t$ test were performed to determine treatment effects of dietary condition (ID or PF). Values are expressed as means \pm standard error of the mean (SEM).

\section{Abbreviations}

Actb: Actin, beta; C: Control; CP: Crossing points; $\triangle$ Cq: Comparative delta quantification cycle; Gapdh: Glyceraldehyde-3-phosphate dehydrogenase: Hprt: Hypoxanthine phosphoribosyltransferase 1; ID: Iron deficiency; IRP: Iron regulatory protein; PF: Pair-fed; Ppia: Peptidylprolyl isomerase A; qPCR: Quantitative real-time polymerase chain reaction; RG: Reference genes; Rpl19: Ribosomal protein L19; Rpl22: Ribosomal protein L22; Rpl27: Ribosomal protein L27; 36b4: Ribosomal protein large P0; Rps29: Ribosomal protein S29; SDCq: Standard deviation crossing point; Tbp: TATA box-binding protein; Tfrc: Transferrin receptor

\section{Acknowledgements}

We thank Mckale Davis Montgomery and Sandra Peterson for their assistance with the 21-day animal experiment. 


\section{Authors' contributions}

JLF and SLC conceptualized the research question; JLF prepared the samples; JLF completed experimental procedures, analysis, interpretation of data, and manuscript preparation. All authors read and approved the final manuscript.

\section{Funding}

This research was supported by National Institutes of Health 1R15DK08872101 (Clarke SL) and National Research Initiative Grant no. 2008-35200-04445 from the United States Department of Agriculture National Institute of Food and Agriculture Bioactive Food Components for Optimal Health Program (Clarke SL).

\section{Availability of data and materials}

The datasets used and/or analyzed during the current study are available from the corresponding author on reasonable request.

\section{Declarations}

Ethics approval and consent to participate

This study was approved by the Oklahoma State University IACUC.

\section{Competing interests}

The authors declare that they have no competing interests.

Received: 7 July 2021 Accepted: 15 September 2021

Published online: 02 October 2021

\section{References}

1. Hentze MW, Muckenthaler MU, Galy B, Camaschella C. Two to tango: regulation of mammalian iron metabolism. Cell. 2010;142(1):24-38. https:// doi.org/10.1016/j.cell.2010.06.028.

2. Andersen $C L$, Jensen JL, Ørntoft TF. Normalization of real-time quantitative reverse transcription-PCR data: a model-based variance estimation approach to identify genes suited for normalization, applied to bladder and colon cancer data sets. Cancer Res. 2004;64(15):5245-50. https://doi.org/10.1158/ 0008-5472.CAN-04-0496.

3. World Health Organization. World prevalence of anaemia 1993-2005. WHO global database on anaemia. World Health Organization. Web. 2014.

4. Georgieff MK. Long-term brain and behavioral consequences of early iron deficiency. Nutr Rev. 2011;69:S43-8. https://doi.org/10.1111/j.1753-4887.2011. 00432.x.

5. Cook JD, Finch CA, Smith NJ. Evaluation of the iron status of a population. Blood. 1976;48(3):449-55. https://doi.org/10.1182/blood.V48.3.449.449.

6. Maher W, Forster S, Krikowa F, Snitch P, Chapple G, Craig P. Measurement of trace elements and phosphorus in marine animal and plant tissues by lowvolume microwave digestion and ICP-MS. Atomic Spectrosc Norwalk Conn. 2001;22(5):361-70.

7. Erikson KM, Pinero DJ, Connor JR, Beard JL. Regional brain iron, ferritin and transferrin concentrations during iron deficiency and iron repletion in developing rats. J Nutr. 1997;127(10):2030-8.

8. Casey JL, Koeller DM, Ramin VC, Klausner RD, Harford JB. Iron regulation of transferrin receptor mRNA levels requires iron-responsive elements and a rapid turnover determinant in the $3^{\prime}$ untranslated region of the mRNA. EMBO J. 1989;8(12):3693-9. https://doi.org/10.1002/j.1460-2075.1989.tb08544. $x$

9. Goforth JB, Anderson SA, Nizzi CP, Eisenstein RS. Multiple determinants within iron-responsive elements dictate iron regulatory protein binding and regulatory hierarchy. Rna. 2010;16(1):154-69. https://doi.org/10.1261/rna.1 857210.

10. Adamski MG, Gumann P, Baird AE. A method for quantitative analysis of standard and high-throughput QPCR expression data based on input sample quantity. PloS One. 2014;9(8):e103917. https://doi.org/10.1371/journa I.pone.0103917.

11. Valasek MA, Repa JJ. The power of real-time PCR. Adv Physiol Educ. 2005; 29(3):151-9. https://doi.org/10.1152/advan.00019.2005.

12. Mullis KB, Faloona FA. [21] Specific synthesis of DNA in vitro via a polymerase-catalyzed chain reaction. MethodsIn Enzymol. 1987;155:335-50. https://doi.org/10.1016/0076-6879(87)55023-6.

13. Wittwer $C T$, Herrmann MG, Moss AA, Rasmussen RP. Continuous fluorescence monitoring of rapid cycle DNA amplification. Biotechniques. 2013;54(6):314-20. https://doi.org/10.2144/000114043.
14. Fleige $S$, Pfaffl MW. RNA integrity and the effect on the real-time qRT-PCR performance. Mol Aspects Med. 2006;27(2-3):126-39. https://doi.org/10.101 6/j.mam.2005.12.003.

15. Bustin SA, Benes V, Garson JA, Hellemans J, Huggett J, Kubista M, et al. The MIQE guidelines: minimum information for publication of quantitative realtime PCR experiments. Clin Chem. 2009;55(4):611-22. https://doi.org/10.13 73/clinchem.2008.112797.

16. Bustin SA. Absolute quantification of mRNA using real-time reverse transcription polymerase chain reaction assays. J Mol Endocrinol. 2000;25(2): 169-93. https://doi.org/10.1677/jme.0.0250169.

17. De Jonge HJ, Fehrmann RS, de Bont ES, Hofstra RM, Gerbens F, Kamps WA, et al. Evidence based selection of housekeeping genes. PloS One. 2007;2(9): e898. https://doi.org/10.1371/journal.pone.0000898.

18. Foss DL, Baarsch MJ, Murtaugh MP. Regulation of hypoxanthine phosphoribosyltransferase, glyceraldehyde-3-phosphate dehydrogenase and beta-actin mRNA expression in porcine immune cells and tissues. Anim Biotechnol. 1998;9(1):67-78. https://doi.org/10.1080/10495399809525893.

19. Ohl F, Jung M, Radonić A, Sachs M, Loening SA, Jung K. Identification and validation of suitable endogenous reference genes for gene expression studies of human bladder cancer. J Urol. 2006;175(5):1915-20. https://doi. org/10.1016/S0022-5347(05)00919-5.

20. Thomas KC, Zheng XF, Suarez FG, Raftery JM, Quinlan KG, Yang N, et al. Evidence based selection of commonly used RT-qPCR reference genes for the analysis of mouse skeletal muscle. PloS One. 2014;9(2):e88653. https:// doi.org/10.1371/journal.pone.0088653.

21. Li B, Matter EK, Hoppert HT, Grayson BE, Seeley RJ, Sandoval DA. Identification of optimal reference genes for RT-qPCR in the rat hypothalamus and intestine for the study of obesity. Int J Obes. 2014;38(2): 192-7. https://doi.org/10.1038/ijo.2013.86.

22. Silver N, Best S, Jiang J, Thein SL. Selection of housekeeping genes for gene expression studies in human reticulocytes using real-time PCR. BMC Mol Biol. 2006;7(1):33. https://doi.org/10.1186/1471-2199-7-33.

23. Suzuki T, Higgins PJ, Crawford DR. Control selection for RNA quantitation. Biotechniques. 2000;29(2):332-7. https://doi.org/10.2144/00292rv02.

24. Zhong H, Simons JW. Direct comparison of GAPDH, $\beta$-actin, cyclophilin, and 285 rRNA as internal standards for quantifying RNA levels under hypoxia. Biochemical and biophysical research communications. 1999;259(3):523-6. https://doi.org/10.1006/bbrc.1999.0815.

25. Mamo S, Gal AB, Bodo S, Dinnyes A. Quantitative evaluation and selection of reference genes in mouse oocytes and embryos cultured in vivo and in vitro. BMC Dev Biol. 2007;7(1):14. https://doi.org/10.1186/1471-213X-7-14.

26. Barber RD, Harmer DW, Coleman RA, Clark BJ. GAPDH as a housekeeping gene: analysis of GAPDH mRNA expression in a panel of 72 human tissues. Physiol Genomics. 2005;21(3):389-95. https://doi.org/10.1152/ physiolgenomics.00025.2005

27. Pfaffl MW, Tichopad A, Prgomet C, Neuvians TP. Determination of stable housekeeping genes, differentially regulated target genes and sample integrity: BestKeeper-Excel-based tool using pair-wise correlations. Biotechnol Lett. 2004;26(6):509-15. https:/doi.org/10.1023/B:BILE.0000019559.84305.47.

28. Davis MR, Rendina E, Peterson SK, Lucas EA, Smith BJ, Clarke SL. Enhanced expression of lipogenic genes may contribute to hyperglycemia and alterations in plasma lipids in response to dietary iron deficiency. Genes Nutr. 2012;7(3):415-25. https://doi.org/10.1007/s12263-011-0278-y.

29. Chen OS, Schalinske KL, Eisenstein RS. Dietary iron intake modulates the activity of iron regulatory proteins and the abundance of ferritin and mitochondrial aconitase in rat liver. J Nutr. 1997;127(2):238-48. https://doi. org/10.1093/jn/127.2.238.

30. Anderson SA, Nizzi CP, Chang Yl, Deck KM, Schmidt PJ, Galy B, et al. The IRP1-HIF-2a axis coordinates iron and oxygen sensing with erythropoiesis and iron absorption. Cell Metab. 2013;17(2):282-90. https://doi.org/10.1016/j. cmet.2013.01.007.

31. Zhao N, Nizzi CP, Anderson SA, Wang J, Ueno A, Tsukamoto H, et al. Low intracellular iron increases the stability of matriptase-2. J Biol Chem. 2015; 290(7):4432-46. https://doi.org/10.1074/jbc.M114.611913.

32. Zhang AS, Xiong S, Tsukamoto H, Enns CA. Localization of iron metabolismrelated mRNAs in rat liver indicate that HFE is expressed predominantly in hepatocytes. Blood. 2004;103(4):1509-14. https://doi.org/10.1182/blood-2 003-07-2378.

33. Xie F, Xiao P, Chen D, Xu L, Zhang B. miRDeepFinder: a miRNA analysis tool for deep sequencing of plant small RNAs. Plant Mol Biol. 2012;80(1):75-84. https://doi.org/10.1007/s11103-012-9885-2. 
34. Biosytems A. User Bulletin\# 2, Relative quantitation of gene expression. AB Prism.;7700:15-36.

35. Dheda K, Huggett JF, Bustin SA, Johnson MA, Rook G, Zumla A. Validation of housekeeping genes for normalizing RNA expression in real-time PCR. Biotechniques. 2004;37(1):112-9. https://doi.org/10.2144/04371RR03.

36. Hruz T, Wyss M, Docquier M, Pfaffl MW, Masanetz S, Borghi L, et al. RefGenes: identification of reliable and condition specific reference genes for RT-qPCR data normalization. BMC Genomics. 2011;12(1):156. https://doi. org/10.1186/1471-2164-12-156

37. Schmittgen TD, Zakrajsek BA. Effect of experimental treatment on housekeeping gene expression: validation by real-time, quantitative RT-PCR. J Biochem Biophys Methods. 2000;46(1-2):69-81. https://doi.org/10.1016/501 65-022X(00)00129-9.

38. Tanic N, Perovic M, Mladenovic A, Ruzdijic S, Kanazir S. Effects of aging, dietary restriction and glucocorticoid treatment on housekeeping gene expression in rat cortex and hippocampus-evaluation by real time RT-PCR. J Mol Neurosci. 2007;32(1):38-46. https://doi.org/10.1007/s12031-007-0006-7.

39. Radonić A, Thulke S, Mackay IM, Landt O, Siegert W, Nitsche A. Guideline to reference gene selection for quantitative real-time PCR. Biochem Biophys Res Commun. 2004;313(4):856-62. https://doi.org/10.1016/j.bbrc.2003.11.177.

40. Derveaux S, Vandesompele J, Hellemans J. How to do successful gene expression analysis using real-time PCR. Methods. 2010;50(4):227-30. https:// doi.org/10.1016/j.ymeth.2009.11.001

41. Solanas M, Moral R, Escrich E. Unsuitability of using ribosomal RNA as loading control for Northern blot analyses related to the imbalance between messenger and ribosomal RNA content in rat mammary tumors. Anal Biochem. 2001;288(1):99-102. https://doi.org/10.1006/abio.2000.4889.

42. Raaijmakers MH, van Emst L, de Witte T, Mensink E, Raymakers RA. Quantitative assessment of gene expression in highly purified hematopoietic cells using real-time reverse transcriptase polymerase chain reaction. Exp Hematol. 2002;30(5):481-7. https://doi.org/10.1016/S0301-472 $X(02) 00787-7$.

43. Jacob F, Guertler R, Naim S, Nixdorf S, Fedier A, Hacker NF, et al. Careful selection of reference genes is required for reliable performance of RT-qPCR in human normal and cancer cell lines. PloS One. 2013;8(3):e59180. https:// doi.org/10.1371/journal.pone.0059180.

44. Najafpanah MJ, Sadeghi M, Bakhtiarizadeh MR. Reference genes selection for quantitative real-time PCR using RankAggreg method in different tissues of Capra hircus. PLoS One. 2013;8(12):e83041. https://doi.org/10.1371/journa I.pone.0083041.

45. Beard J. Iron deficiency alters brain development and functioning, 2. J Nutr. 2003;133(5):1468S-72S. https://doi.org/10.1093/jn/133.5.1468S.

46. Punnonen $\mathrm{K}$, Irjala K, Rajamäki A. Iron-deficiency anemia is associated with high concentrations of transferrin receptor in serum. Clin Chem. 1994;40(5): 774-6. https://doi.org/10.1093/clinchem/40.5.774.

47. Schmittgen TD, Livak KJ. Analyzing real-time PCR data by the comparative C $T$ method. Nat Protoc. 2008;3(6):1101-8. https://doi.org/10.1038/nprot.2008.73.

\section{Publisher's Note}

Springer Nature remains neutral with regard to jurisdictional claims in published maps and institutional affiliations.

Ready to submit your research? Choose BMC and benefit from:

- fast, convenient online submission

- thorough peer review by experienced researchers in your field

- rapid publication on acceptance

- support for research data, including large and complex data types

- gold Open Access which fosters wider collaboration and increased citations

- maximum visibility for your research: over $100 \mathrm{M}$ website views per year

At BMC, research is always in progress.

Learn more biomedcentral.com/submissions 